\section{Magalu Has It: Social, Political, and Market Strategies during COVID-19}

\author{
Tem no Magalu: Estratégias Sociais, Políticas e de Mercado Durante a \\ COVID-19
}

Discipline: Strategy

Subject: Market Strategies, Non-market Strategies

Industry: Retail

Geography: São Paulo/Brazil
Ana Paula Pereira dos Passos ${ }^{1}$ Eleandra Maria Prigol Meneghini ${ }^{16}$ Marina Amado Bahia Gama ${ }^{2}$ Jeferson Lana' ${ }^{10}$

\title{
INTRODUCTION
}

In February 2020, José Ribeiro, director of Institutional Relations at Magazine Luiza group (Magalu), one of the largest retailers in the country, observed what was happening in the world and in Brazil. At that time, Brazil had registered its first case of COVID-19. The disease spread across the country in a devastating speed. In view of the high number of cases and deaths, social isolation was established, in which firms from different sectors were quarantined with no forecast of returning to normal.

Social isolation had an inevitable impact on the economy. Many firms had paralyzed their activities and the internal and external demand had been reduced. This caused a drop on revenues and, as a result, a need for financial support from the government to reduce the risk of

1. Universidade do Vale do Itajaí, Programa de Pós-graduação em Administração, Itajaí, SC, Brazil.

2. Fundação Getulio Vargas, Escola de Administração de Empresas de São Paulo, São Paulo, SP, Brazil

Cite as: Passos, A. P. P., Meneghini, E. M. P., Gama, M. A. B., \& Lana, J. (2021). Magalu has it: Social political, and market strategies during COVID-19. Revista de Administração Contemporânea, 25(spe), e200233. https://doi.org/10.1590/1982-7849rac2021200233.en layoffs and bankruptcy of firms. The Brazilian government, pressured by businessmen and fearing yet another huge crisis, established provisional measures (PMs) in this regard. However, there was concern about its effectiveness and about the downtime that firms would endure.

In March 2020, José Ribeiro, along with an urgent affairs committee, decided to adhere to social isolation due to the pandemic, and Magalu had to temporarily close the doors of more than 1,000 stores in the country during the lockdown period. At that time, Luiza Helena Trajano, owner and chairman of the board of directors, was one of the leaders of the manifesto \#NãoDemita (do not fire the employees) and made a commitment not to fire any employee.
JEL Code: A20, L81, L1

Editor-in-chief: Wesley Mendes-da-Silva (Fundação Getulio Vargas, EAESP, Brazil) 두 Associate Editor: Paula C. P. de S. Chimenti (Universidade Federal do Rio de Janeiro, COPPEAD, Brazil) Guest Editor: Leonardo Marques (Universidade Federal do Rio de Janeiro, COPPEAD, Brazil) (I]) Reviewers: The reviewers did not authorize the disclosure of their identities.

Peer Review Report: The disclosure of the Peer Review Report was not authorized by its reviewers.

Received: July 17, 2020 Last version received: December 07, 2020 Accepted: December 08, 2020

\begin{tabular}{|c|c|c|c|c|c|c|c|c|c|}
\hline & 1 & 2 & 3 & 4 & 5 & 6 & 7 & 8 & 9 \\
\hline $1^{\text {st }}$ round & $\stackrel{8}{2}$ & 电 & & & & & & & \\
\hline $2^{\text {nd }}$ round & & & & & & & & & \\
\hline
\end{tabular}


Luiza was involved in the discussions related to the PMs from her performance on the board of the Brazilian Institute of Retail (Instituto Brasileiro de Varejo - IBV). She was with the Federal Government, as well as in other bodies, to help in the creation of the PMs, and made efforts to disseminate them, simplifying the communication 'FROM' (as it was) - 'TO' (how it became), on its social networks, with the intention that the information would reach all interested parties in a clear manner (Annex A). In addition, in partnership with the Brazilian Micro and Small Enterprises' Support Service (Serviço Brasileiro de Apoio às Micro e Pequenas Empresas - Sebrae), Luiza offered training to small- and medium-sized firms and, considering the increase in cases of violence against women throughout social isolation, carried out campaigns to expand denunciations, through its leadership in the Brazilian Women Group.

The Magalu group, represented by José Ribeiro and the urgent affairs committee, was similarly committed to facing COVID-19. In this sense, it contributed ten million reais in equipment and supplies for the treatment of victims of the pandemic; one million reais for the non-governmental organization (NGO) Amigos do Bem (Friends of Good); 20 thousand reais in blankets intended to equip the new temporary reception centers in São Paulo (SP); and four thousand reais in mattresses and pillows, donated to the state governments of Pará and Bahia. It also donated cardiac monitors to Hospital Emílio Ribas, in São Paulo, and lung ventilators to a unit of the Unified Health System (Sistema Único de Saúde - SUS) located in Vila Guilherme, and another to Santa Casa in the municipality of Franca, in the interior of the state of São Paulo. It also launched Parceiro Magalu, a digital platform designed to ensure online sales and provide a new source of income to people who had been fired. Thus, the platform was intended for self-employed workers, individual microentrepreneurs (MEI), and small retailers who wanted to sell their own products and/or sell products of the Magalu group.

Thus, since the beginning of the pandemic, Luiza, José Ribeiro, and the entire Magalu have implemented measures focused on improving the social conditions of their main stakeholders, while maintaining concern for shareholders' profitability. The involvement on behalf of its employees and Brazilian society was remarkable. His efforts to help small- and medium-sized businesses and those most affected by the crisis were highlighted in the national news.

In July 2020, the situation had not yet stabilized, the number of cases and deaths increased, and little was known about when the daily life would return to 'normal.' Many questions persisted about the next strategies that would be taken by national firms, including those in Magalu. José Ribeiro and the urgent affairs committee wondered if they were on the right track: Would the group be able to maintain a balance between market strategies - through actions for customers, employees, suppliers, and shareholders and non-market strategies - through political and social actions? How could the group continue to position itself to ensure performance and reputation?

\section{BACKGROUND OF LUIZA AND MAGALU}

It all started in 1957, with Luiza's uncles, the couple Luiza Trajano and Pelegrino José Donato, who acquired a small store called $A$ Cristaleira, located in the municipality of Franca, in the state of São Paulo. Later, the store was called Magazine Luiza, in a cultural contest. Gradually, with cash on hand, from family members, the business expanded. Upon completing 20 years of activity, Magazine Luiza already had 30 stores. The 1980s were marked by the automation and computerization of these stores, the creation of the first distribution center (DC), and the expansion of the firm outside the state. But it was in 1990 that the firm made a big leap, with the consolidation of the Magalu group.

In 1991, Luiza took over the leadership of the group and promoted the decentralization of command, giving employees an active voice in decisions and preventing family egos from interfering with the firm's growth. In 1992, the first virtual stores were launched and, in 1993, a policy of distributing the firm's profits to employees was implemented.

In that decade, the holding was created to manage the expansion of the group, in addition to the electronic stores, the Só Amanhã project, and the Liquidação Fantástica campaign. In 1998, Magalu was included in the list of the best firms to work for in Brazil ${ }^{1}$ and, in 2003, it reached the first place in this ranking. In 2011, the firm went public on the Bolsa de Valores de São Paulo (B3), with exclusively common shares. In the following year, 2012, Luiza created the Brazilian Women Group together with 50 women working in different segments of the economy, in favor of a common objective: to help the country's growth.

The third generation of heirs in control of Magalu took place in 2016, when Frederico Trajano, Luiza's son, took over as CEO of the group and she became chairman of the board of directors. Always concerned about the network's employees, in 2017, Luiza created a hotline to help the workers report the aggressors, in case they were victims of domestic violence. In 2019, Magalu was awarded by InfoMoney as the Best Company on the Stock Exchange. In 2020, it had more than a thousand stores in the country. The brand's marketplace gathered more than eight thousand sellers. Owner of the Netshoes, Zattini, and Shoestock platforms, in addition to retail, she worked with 
financial products, the Luizacred credit card, the Luizaseg insurance, and the Luiza Consortium.

Luiza was known for having transformed a discreet chain store into a chain present throughout the national territory, with almost 40 thousand employees and one of the most coveted titles in B3. But it was her performance in confronting SARS-CoV-2 that put her on the main news channels in the country. In an interview, in April 2020, she demonstrated her experience in overcoming crises and called on everyone to unite around a single objective, to defeat the virus: "I was more of an entrepreneur in the crisis than out of the crisis. I always looked for solutions and not the culprits. At the moment, the culprit is a virus. We will seek a solution" (Luiza Helena Trajano, 2020).

\section{POLITICAL AND SOCIAL ACTIONS OF LUIZA AND MAGALU, BEFORE THE APPEARANCE OF COVID-19}

Luiza stood out for her close connection with Magalu's customers and employees and for her proximity to the country's political and social environment. In 2006, during the government of President Luiz Inácio Lula da Silva, Magalu was approved as a partner of the Federal Government's digital inclusion Computador para Todos program, through two financing carried out by the National Bank for Economic and Social Development (Banco Nacional de Desenvolvimento Econômico e Social - BNDES): the first, of 30 million reais, referring to 23 thousand popular computers; and the second, of 50 million reais, for the acquisition of 40 thousand pieces of equipment in the program. Part of the group's growth occurred through financing from BNDES, and between 2002 and 2012 the group raised about 210 million reais, as shown on the state bank's website. This money financed the opening and renovation of stores, the acquisition of equipment and trucks, and the expansion of business across the country.

In addition, while the donations to electoral campaigns in Brazil were allowed, José Ribeiro, along with his team, was active in making decisions for Magalu to donate both to candidates and to political parties. In this sense, there are records of donations from the group in the years 2004, 2006, 2008, 2010, 2012, and 2014, totaling approximately 500 thousand reais for 14 political parties, listed below, in descending order from the largest amounts received: DEM, PT, PMDB, PPL, PSDB, PSB, PV, PR, PDT, PPL, PSD, and PCdoB.

Later, in 2013, during the government of President Dilma Rousseff, Luiza praised the subsidized credit offered by the Federal Savings Bank (Caixa Econômica Federal) to beneficiaries of the Minha Casa Minha Vida program for the purchase of appliances and furniture through the Minha
Casa Melhor program, which provided for 18 million in loans at interest of 5\% per year. José Ribeiro, in charge of the group's institutional relations, participated directly in the discussions of the Minha Casa Melhor program with the federal government.

In 2014, President Dilma Rousseff met with Luiza and asked her for help in bringing the government closer to the Brazilian business community. The request was granted in December 2014, in a presidential meeting coordinated by the businesswoman with about one hundred businesswomen from the Brazilian Women Group. At this meeting, the president repeated twice that Luiza had already been invited in 2011 to occupy a ministry in her government and that she was not part of it by choice. In 2018, the businesswoman defined herself as non-partisan: "I am neither left nor right. I travel a lot in the interior of Brazil. I know what it is not to have water, I know how important the Bolsa Familia was, just as I also know how good the free market is. A proposal can be a good one coming from the left or from the right. The new labor law, for example, I am sure it did not harm the worker in any way" (Luiza Helena Trajano, 2020).

Magalu also stood out for the development of social actions. In 1998, it joined the Instituto Ethos. In 1999, it created the Acadêmicos website and participated in the Adote um Universitário program. In 2010, through the Rede do Bem project, it engaged employees in social actions, such as clothing campaigns and blood donation. In the same year, José Ribeiro inserted, in the contracts with suppliers, a specific clause on social and environmental responsibility, which guaranteed compliance with legislation, preservation of the environment, and respect for people and human rights.

In 2013, part of the group's truck fleet started using audit systems that monitored $\mathrm{CO}_{2}$ emissions. In 2014, José Ribeiro was active in the Magalu to create the Comitê de Energia e Água, to implement measures to reduce and optimize the use of these resources. In the same year, it joined the Pact of Commitment and Attitude through the Maria da Penha Law, promoted by the secretariat of policies for women of the Presidency of the Republic; internally, developed the Mulheres em Ação project to provide support to those who needed it, and signed the commitment, at the $2^{\text {nd }}$ Fórum de Mulheres Líderes, to increase the number of women in leadership positions. In addition, starting in 2015, considering the reports published by the group, Magalu joined the Instituto Pró-Criança, being one of the leading companies in the movement that worked to eradicate child labor.

Also according to the 2015 and subsequent reports, the institutional relations area instituted practices for preservation and awareness, such as the adoption of selective collection dumps in offices and DC, projection on the DC, to take advantage of natural lighting and rainwater; use of wooden pallets with certification of sustainable management 
of forests, and sheets of recyclable paper; availability of the Carona Amiga project, to help employees plan rides in solidarity; and developed awareness campaigns such as Sua Empresa, Sua Casa and Hora do Planeta, through the NGO World Wildlife Fund (WWF). In addition, it developed programs to include and respect differences within the firm, such as encouraging the hiring and inclusion of people with disabilities, adapting the facilities and training employees, and assisting women who wish to grow professionally.

Magalu invested in social projects through the National Program to Support Oncological Care and the National Program to Support Health Care for People with Disabilities. It contributed to the Municipal Fund for Children and Adolescents. It maintained a voluntary personal performance in public entities in Franca (SP). It became involved in the Outubro Rosa movement, to publicize the importance of early detection of breast cancer. Its managers also received resources to support community events and participate in campaigns and mobilizations for the benefit of society. Each unit of the group had autonomy to respond to requests for donations and sponsorships, but priority was given to those benefiting social institutions, such as schools, women's police stations, hospitals, nursing homes, and Associations of Parents and Friends of Exceptional People (APAEs).

According to data published on its website, Magalu kept active in projects of the Paraisópolis community, such as the Paraisópolis Philharmonic Orchestra and the Judô para Todos project. It was the main maintainer of the Cancer Hospital of Franca and financially supported the Santa Casa of the municipality. One of the group's partners voluntarily assumed the administrative direction of Santa Casa. Also in 2018, on Women's Day, the group created the campaign Meteu a Colher, in which it sold 20,000 units of a special spoon, engraved with the words "\#eumetoacolhersim Ligue 180 e denuncie." The action raised 36,000 reais, the group tripled that amount and donated it to the Instituto Patrícia Galvão and the Mete a Colher collaborative network.

\section{THE CONFRONTATION WITH SARS-COV-2: ACTIONS OF THE BRAZILIAN GOVERNMENT AND THE POSITIONING OF LUIZA AND THE MAGALU GROUP}

In December 2019, China turned on the yellow light by confirming the presence of a new virus, the coronavirus, which in just two months would contaminate all continents. In February 2020, Brazil registered its first case of COVID-19. In mid-March, the first death occurred and, from then on, the disease started to spread in the country. The Ministry of Health and state governments have established social isolation, in which schools, universities, non-essential firms, and other firms have been quarantined. And there was no forecast of returning to normal. Despite the Federal Government's first measure defining the 15-day period for isolation, everyone understood that this period would not be enough to control the spread of the disease, as in other countries the quarantine reached three months.

In these circumstances, the International Monetary Fund (IMF) was forecasting that the Brazilian gross domestic product (GDP) would fall by $5.3 \%$ and the unemployment rate would reach $14.7 \%$. The Federal Government, pressured by businessmen and afraid of yet another huge crisis, decided to take action. On March 13, 2020, the first PM (provisional measure) for the fight against COVID-19, PM 924, came out, which authorized five billion reais in extraordinary credits for the Ministries of Health and Education. Following, the Planalto Palace started to implement a series of PMs, which included the creation of programs to maintain jobs during the crisis (PM 927); credit lines for firms (PM 944); sharing of labor charges (PM 936); measures for the energy (PM 950), tourism and culture (PM 948), ports (PM 945), and telecommunications (PM 952) sectors; the release of FGTS funds (PM 946); the recomposition of state and municipal participation funds (PM 938); simplification of public procurement (PM 951); and facilitating access to credit (PM 958).

José Ribeiro, together with the urgent affairs committee, made the decision to adhere to social isolation. Thus, Magalu was one of the first firms to join the isolation, announcing the closure of more than a thousand physical stores in March 2020. At first, the group made a commitment to preserve jobs. Even before the publication of the PMs of the Federal Government, the group did not carry out layoffs. Of its nearly 40 thousand permanent employees, 20 thousand had their vacations anticipated, even those that had not expired. The employees who were in the trial period were dismissed; however, each received a thousand reais as aid, in addition to having their other rights guaranteed. Of those employees, those who had left their jobs to work in the group were kept. Magalu also made some extra concessions to employees: anticipated the food tickets and doubled the amount of the daycare allowance, to allow it collaborators to hire caregivers for their children during the period when they would continue to work, since the children would not be attending school.

Since the beginning of the pandemic, Luiza has stood out as an influential business leader in the country. She was invited to participate in a series of interviews, engaged in media discussions related to COVID-19, shared news weekly on her Instagram (@luizahelenatrajano) and LinkedIn (/luizahelenatrajano), and created her own YouTube channel (named Luiza Helena Trajano). The businesswoman led 
the Brazilian Women Group, which, in 2020, added more than 40 thousand members who discussed and proposed actions related to education, entrepreneurship, and quotas for women. In partnership with Sebrae, Luiza also offered training for small- and medium-sized companies. In addition, during social isolation, with the increase in cases of violence against women, campaigns were carried out to expand complaints using Magalu's service channels and its social media. For example, on LinkedIn, the businesswoman posted: "Very important is the red light campaign against domestic violence, which aims to offer a silent channel of denunciation to victims who are prevented from calling the police at their homes, due to the violence suffered, allowing them to identify themselves in pharmacies and drugstores. If you are experiencing domestic violence, ask for help" (Luiza Helena Trajano, 2020).

For Luiza, the first PMs adopted by the Federal Government were well suited to cope with the situation, as well as the \#NãoDemita movement, created together with other entrepreneurs. The businesswoman worked to make the PMs a reality. Before the pandemic, Luiza gave lectures to small- and medium-sized companies and, based on her role on the IBV board, she worked with the government and other bodies to help create these PMs. She then found several secretaries to deal with the matter and helped disseminate the PMs, simplifying the communication 'FROM' (as it was) - 'TO' (how it became) on their social media, with the intention that the information would reach all concerned clearly. In an interview with UOL Debate channel, in 2020, Luiza reinforced the defense that the PMs reach the needy population: "We studied a lot. Our struggle, which I spoke with the secretary of the treasury, is that these measures have to reach the tip. These measures took working capital, a guarantee fund, taxes, it was important. Now, I want to ask everyone to get to the tip [of the autonomous]" (Luiza Helena Trajano, 2020).

Still, the businesswoman reported how impressed she was with the improvement of the donation culture in the country. In comparison to other developing countries, Brazil had a timid performance, but, during the pandemic, there was a movement to benefit donations from firms and individuals. In addition to several specific actions, five billion reais were donated in two months. In other words, in Brazil, the pandemic brought a new look to corporate philanthropy and the responsibility of firms to society. In a post on LinkedIn, Luiza commented on the importance of uniting everyone to face SARS-CoV-2: "We have only one enemy, the virus. And against it and its consequences, we have to fight. We have to focus on health and the economy. $\mathrm{CPF}$ you can't get another one. Employment gives dignity and support ... A new reality awaits us, and the only thing we know is that it will not be easy. But together in the same focus, it will be easier" (Luiza Helena Trajano, 2020).
In the same way that Luiza acted since the beginning of the pandemic, José Ribeiro and his team at the head of Magalu were also committed. Magalu got involved in social networks sharing tips and spreading useful information from authorities and the government about COVID-19 on a daily basis. It allocated free shipping to the categories of products in immediate need, such as protective masks, nebulizers, and alcohol gel. In March 2020, in order to collaborate with the entire corporate philanthropy movement that was happening in the country, it contributed ten million reais in equipment and supplies for the treatment of the victims of the pandemic; a million reais for the NGO Amigos do Bem, which worked to improve the living conditions of poor people in the northeastern hinterland; 20 thousand blankets to equip the new temporary reception centers, in the state of São Paulo; and four thousand reais in mattresses and pillows for the state governments of Pará and Bahia. It also donated cardiac monitors to Hospital Emílio Ribas, in São Paulo; pulmonary ventilators for a SUS unit located in Vila Guilherme (SP) and for Santa Casa in the city of Franca (SP).

Like other Brazilian firms, the Magalu group also sought to increase online sales. Its salespeople already used an application implemented in 2016, however, in a restricted way. During social isolation, new home office sales channels were enabled in the application and it was integrated with the most popular social networks. The group had already been investing in digital technologies over the years. In 2017, the group incorporated Integra, focused on the integration of electronic commerce and marketplaces and, in 2018, acquired Softbox, a developer of online sales services for retail companies, and Logbee, a startup specialized in logistics technology.

The group reached the beginning of 2020 with over a thousand physical stores, almost 40 thousand employees, and one of B3's most coveted roles. With a marketplace of more than eight thousand sellers, it owned the Netshoes, Zattini, and Shoestock platforms and, in addition to retail, it operated with financial products, with the Luizacred credit card, the Luizaseg insurance, and the Luiza Consortium. It also had three innovation laboratories, in which 800 engineers worked. In other words, Magalu had resources and capabilities that enabled the launch of Parceiro Magalu, in the midst of the pandemic, a digital platform that aimed to ensure online sales and provide a new source of income for people who were fired.

In the first days of its launch, in March 2020, the Parceiro Magalu platform reached 160 thousand subscribers to sell the group's products, and 30 thousand to sell their own products. The platform was aimed at individuals, MEI, and small retailers who could register for free and remain active without monthly fees. 
Individuals could sell products from Magalu and other traders, offered in the marketplace, receiving a commission between $1 \%$ and $12 \%$, depending on the product, category, and volume sold. Using the logistics network, MEI and small retailers could sell Magalu products and their own products to all interested customers. The whole process took place in a simplified way: salespeople inserted the products into the platform and a fee was charged by the company only when the sale occurred. Frederico Trajano, the group's CEO, reported on the Parceiro Magalu, in an interview in 2020: "We are not making money in the short term, with the platform. It does have a strategic purpose, it is not charity, it has a longterm context, but at that moment it is fully subsidized, it has no profit from tragedy. After these three months, the commission is likely to rise" (Frederico Trajano, 2020).

The group had three innovation laboratories, called Luizalabs. More than 800 engineers worked on them, and during the pandemic, a team was established to monitor COVID-19 cases in the cities where physical stores were located. The intention was to monitor the data related to the pandemic and, when the trade was released, they would have information to decide if it would be the best time to reopen the store in question. According to Frederico Trajano at the end of March 2020: "our position today is to wait until we ensure that the safety and health protocols of workers and customers have adhered and that we are comfortable with them."

At the end of 2019, Magalu had seven billion reais in cash. In April 2020, the firm approved the issuance of 800 million reais in debentures; renegotiated contracts with direct and indirect suppliers to extend payment terms; made cost cuts not related to people; and suspended some investments. It also implemented measures to reduce the payroll, and the executives had an effective cut in salaries for a period of three months. The remuneration of the CEO, Frederico Trajano, and of the vice president of operations, Fabrício Bittar Garcia, was reduced by $80 \%$. The remuneration of the 12 executive officers was reduced by $50 \%$, as well as the earnings of the seven members of the board of directors; and the earnings of the other directors was reduced by $25 \%$. Although Magalu continues with its commitment to secure jobs, the firm also used PM 936, which allowed the suspension of employment contracts for up to 60 days and the proportional reduction, for three months, of up to $70 \%$ of hours and salaries, complementing these salaries with federal resources.

In May 2020, Luiza began to demonstrate, in the interviews, her concern about the effectiveness of the Federal Government's PMs. The businesswoman reported: "I found the measures [of the economic team] very fast for such a large and bureaucratic Brazil. Now, the problem is that you are in this fight [discussions without purpose] and not divulging the measures [in an appropriate way]."

She also added that Magalu had not dismissed employees due to the pandemic, but started to make a reservation: "what we guarantee is not to dismiss during these two, three months. Now, we cannot guarantee that we will not fire our whole lives. We will fight hard for this. That's why I'm struggling with the measures."

For Luiza, the PMs needed to be revised, since it was not possible to create a complete package of measures, and the scenario of instability continued in the country.

\section{WHAT TO EXPECT?}

Since the beginning of the disease in Brazil, Luiza, José Ribeiro, and the urgent affairs committee representing Magalu have engaged in discussions in the media and have taken a series of measures both internal and external to the company. These measures were aimed to improving the social conditions of its main stakeholders, without neglecting the concern for shareholders' profitability. In July 2020, instability was still perceived in Brazil, the number of cases and deaths rose, and little was known about when the daily life would return to 'normal.' Many questions persisted about the firms' next strategies, including Magalu. José Ribeiro and the urgent affairs committee questioned themselves: Would the group be able to maintain a balance between market strategies through actions for customers, employees, suppliers, and shareholders - and non-market strategies — through political and social actions? If, on the one hand, there was a need to implement market strategies to ensure organizational performance, on the other hand, Luiza and Magalu have always invested in social and political actions, positioning themselves as a group concerned with stakeholders.

In addition, José Ribeiro and the urgent affairs committee asked: In Brazil, to implement non-market strategies, in particular to address the issue of corporate social responsibility (CSR), which is increasingly discussed and highlighted in other countries and with space on the agenda of major investors in the world, could help Magalu ensure its continuity without losing its reputation? What other strategies could be implemented to maintain the reputation built? How could the group continue to integrate strategies into the market and non-market environment and generate competitive advantage? Luiza's stance during the pandemic took on a greater role than the greatness of Magalu. However, to what extent do Luiza's social and political actions favor the group? Should Luiza continue 
to face these actions in place of the current CEO? Did COVID-19 question Luiza and Magalu's model, or did it strengthen it?

\section{NOTE}

1. Promoted by Revista Exame, in partnership with Great Place to Work Institute. 


\section{ANNEX A.}

Table A1. Provisional measures (PSs) implemented by the Federal Government and presented by Luiza on her social networks.

\begin{tabular}{|c|c|c|c|c|}
\hline Group & Measure & How it was & How it became & Source \\
\hline \multirow{7}{*}{ 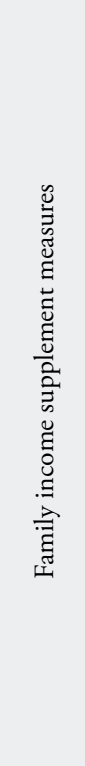 } & $\begin{array}{l}\text { Anticipation of the 13th salary for } \\
\text { retirees and pensioners }\end{array}$ & $\begin{array}{l}\text { Payment of the } 1 \text { st and } 2 \text { nd installments of } \\
\text { the } 13 \text { th salary occurred in the months of } \\
\text { November and December }\end{array}$ & $\begin{array}{l}\text { Anticipation for April and May of the } 1 \text { st and } 2 \text { nd installments of } \\
\text { the 13th salary of retirees and pensioners of INSS. }\end{array}$ & G1 website \\
\hline & $\begin{array}{l}\text { Reinforcement of the Bolsa Família } \\
\text { program }\end{array}$ & $\begin{array}{l}\text { Prior suspension with blocks and stricter } \\
\text { registration verification to grant the benefit }\end{array}$ & $\begin{array}{l}\text { Provision of additional credit of } \mathrm{R} \$ 3 \text { billion and easier inclusion } \\
\text { of more than } 1 \text { million people in the program. }\end{array}$ & $\begin{array}{l}\text { PM No } \\
929 / 2020 \text { and } \\
\text { Ordinance No } \\
335 / 2020\end{array}$ \\
\hline & $\begin{array}{l}\text { Possibility of withdrawing amounts } \\
\text { from PIS/Pasep through FGTS }\end{array}$ & $\begin{array}{l}\text { Workers entitled to withdraw from PIS } \\
\text { had a deadline for withdrawal }\end{array}$ & $\begin{array}{l}\text { The amounts not withdrawn will be transferred to the workers' } \\
\text { FGTS accounts, allowing the withdrawal of these amounts. }\end{array}$ & G1 website \\
\hline & Guarantee of electricity supply & $\begin{array}{l}\text { The lack of payments allowed the } \\
\text { suspension of electricity supply }\end{array}$ & $\begin{array}{l}\text { Prohibition of suspension of electricity supply due to lack of } \\
\text { payments, including from the low-income population. }\end{array}$ & $\begin{array}{l}\text { Aneel } \\
\text { Normative } \\
\text { Resolution No } \\
878 / 2020\end{array}$ \\
\hline & $\begin{array}{l}\text { Voucher for freelancers, informal, and } \\
\text { intermittent }\end{array}$ & $\begin{array}{l}\text { Absence of financial benefits other than } \\
\text { those provided for by Social Security }\end{array}$ & $\begin{array}{l}\mathrm{R} \$ 600 \text { voucher for three months for informal, self-employed, } \\
\text { and intermittent workers, fulfilling some predetermined } \\
\text { requirements. }\end{array}$ & \multirow{2}{*}{$\begin{array}{l}\text { Law No } \\
13,982 / 2020\end{array}$} \\
\hline & $\begin{array}{l}\text { Voucher for head of household (single } \\
\text { parent) }\end{array}$ & $\begin{array}{l}\text { Absence of financial benefits other than } \\
\text { those provided for by Social Security }\end{array}$ & $\begin{array}{l}\text { Two-share voucher, totaling } \mathrm{R} \$ 1,200 \text {, for three months for a } \\
\text { mother and householder. }\end{array}$ & \\
\hline & Release of FGTS partial withdrawal & $\begin{array}{l}\text { Release of FGTS withdrawal only in } \\
\text { the cases expressly provided for in the } \\
\text { legislation }\end{array}$ & $\begin{array}{l}\text { Possibility for each worker to receive from June } 29,2020 \text { up to } \\
\mathrm{R} \$ 1,045 \text { of FGTS deposited in his active (current job) or inactive } \\
\text { (previous job) accounts. }\end{array}$ & G1 website \\
\hline \multirow{8}{*}{ 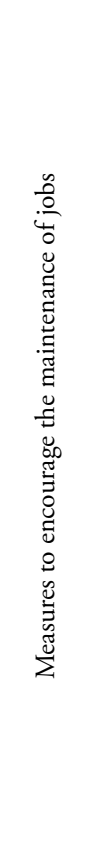 } & Postponement of FGTS payment & $\begin{array}{l}8 \% \text { monthly payment on employees' } \\
\text { wages and salaries under FGTS }\end{array}$ & $\begin{array}{l}\text { Suspension of FGTS payment for three months, with the balance } \\
\text { to be paid in six installments as of July/2020. }\end{array}$ & \multirow{7}{*}{$\begin{array}{l}\text { PM No } \\
927 / 2020\end{array}$} \\
\hline & Anticipation of individual vacations & $\begin{array}{l}\text { Obligation of the employee to have } \\
\text { worked at least one year and to be notified } \\
30 \text { days in advance }\end{array}$ & $\begin{array}{l}\text { Possibility of anticipating employees' vacations even without the } \\
\text { full vesting period, as long as the notice is } 48 \text { hours in advance. }\end{array}$ & \\
\hline & $\begin{array}{l}\text { Simplified collective vacation } \\
\text { concession }\end{array}$ & $\begin{array}{l}\text { Need to communicate to the Unions and } \\
\text { Ministry of Labor, in addition to notifying } \\
\text { employees at least } 30 \text { days in advance }\end{array}$ & $\begin{array}{l}\text { Possibility to notify the group of employees } 48 \text { hours in advance, } \\
\text { without the need to communicate to the unions and Ministry } \\
\text { of Labor. }\end{array}$ & \\
\hline & $\begin{array}{l}\text { Simplified regulation of telecommuting } \\
\text { or home office }\end{array}$ & $\begin{array}{l}\text { Need for prior provision in individual or } \\
\text { collective agreement on the possibility of } \\
\text { telecommuting (home office) }\end{array}$ & $\begin{array}{l}\text { Possibility of deploying telework (home office) only with } \\
\text { notification to the employee } 48 \text { hours in advance. }\end{array}$ & \\
\hline & $\begin{array}{l}\text { Bank of hours in the period of public } \\
\text { calamity }\end{array}$ & $\begin{array}{l}\text { Need prior individual agreement with } \\
\text { employees for the establishment of hour } \\
\text { bank }\end{array}$ & $\begin{array}{l}\text { During the public calamity, the creation of the hour bank in favor } \\
\text { of the employer is allowed, which can be compensated within } 18 \\
\text { months after the calamity. }\end{array}$ & \\
\hline & Anticipation of holidays & $\begin{array}{l}\text { Holidays should be taken on the respective } \\
\text { festive or religious dates }\end{array}$ & $\begin{array}{l}\text { Companies can anticipate the enjoyment of holidays by } \\
\text { employees, as long as they notify them } 48 \text { hours in advance. } \\
\text { Religious holidays depend on mutual agreement. }\end{array}$ & \\
\hline & $\begin{array}{l}\text { Suspension of occupational health } \\
\text { requirements }\end{array}$ & $\begin{array}{l}\text { Mandatory periodic and admission } \\
\text { examinations, as well as legal training on } \\
\text { health and safety }\end{array}$ & $\begin{array}{l}\text { Suspension of the need for exams and training during the public } \\
\text { calamity period. }\end{array}$ & \\
\hline & $\begin{array}{l}\text { Reduction of contributions to Sistema } \\
\text { S }\end{array}$ & $\begin{array}{l}5.8 \% \text { monthly payment on wages } \\
\text { and salaries in the case of commercial } \\
\text { companies }\end{array}$ & $\begin{array}{l}\text { Partial reduction in contributions to Sistema } S \text { for three months, } \\
\text { from April to June. For commerce, the percentage was reduced } \\
\text { to } 4.55 \% \text {. }\end{array}$ & $\begin{array}{l}\text { PM No } \\
932 / 2020\end{array}$ \\
\hline
\end{tabular}


Table A1. (Continued)

\begin{tabular}{cc}
\hline Group & Measure \\
\hline & Possibility of reducing wages and
\end{tabular}
working hours

Suspension of the employment contract
Partial postponement of the amount of tax due - Simples Nacional

Financing of salaries for small- and medium-sized enterprises

Exemption from IPI to combat COVID-19

Reduction of ICMS to combat COVID-19 in DF, RJ, BA, MA, PA, and PI

Postponement of the employer's social security contribution

Postponement of contributions to PIS/Cofins

Extension of delivery of the DCTF

Extension of EFD delivery contributions
There were few chances of suspension of the employment contract and all with very restricted application
How it was

There was no clear provision in the legislation that would allow the reduction of wages and working hours under any circumstances

a) Companies can negotiate with their employees a reduction of $25 \%, 50 \%$, or $70 \%$ of the workday and salary, according to the rules indicated in the table below and respecting the maintenance of the employee's hourly wage;

b) Employee agreement is required for the reduction to take effect; c) Reduction period: 90 days — during the period of public calamity;

d) Salary of up to $\mathrm{R} \$ 3,135$ - individual agreement, communication with two days in advance, notice to the union;

f) Salary between $\mathrm{R} \$ 3,135$ and $\mathrm{R} \$ 12,202$ - only by means of a collective agreement with participation of the union;

g) Salary above $\mathrm{R} \$ 12,202$ (hypersufficient as long as the employee has a higher education); individual agreement, notice to the union;

h) The company may provide the employee with monthly compensatory aid (without salary nature - free of taxes);

i) Guarantee of the employee's stability for twice the term of the reduction of the working day and salary.

a) The contract can be suspended by the company as long as it communicates the employee with two days in advance;

b) All employees are eligible for the company to apply the suspension of the employment contract;

c) Maximum term: 60 days - during the period of public calamity; it can be divided into two periods;

d) There must be no provision of service by the employee to the company during the suspension period;

e) Salary of up to R\$3,135 - individual agreement and notice to the union;

f) Salary between R $\$ 3,135$ and $R \$ 12,202$ - only by means of a collective agreement with participation of the union;

g) Salary above $\mathrm{R} \$ 12,202$ (hypersufficient as long as the employee has a higher education); individual agreement and notice to the union;

h) All employee benefits must be maintained;

i) Guarantee of employee stability for twice the term of suspension of the employment contract;

j) Compulsory compensatory aid of $30 \%$ of salary for companies with annual gross revenue above $\mathrm{R} \$ 4.8$ million.

Monthly percentage payment on the revenue of Simples Nacional companies, which included federal, state, and municipal taxes

There was no specific credit line to finance salaries

IPI requirement on imported or domestically produced goods

Requirement of full ICMS tax burden on goods sold in the territory of the states

Monthly payment of $20 \%$ on the remuneration of employees, independent workers, and individual taxpayers, in addition to the so-called contribution to the RAT/FAP

Monthly percentage payment on companies' gross revenue, which may vary depending on the type of economic activity and the annual volume of these revenues

Monthly delivery of the Declaração de Débitos e Créditos Tributários Federais (DCTF) by the 15th business day of the second month after competence

Monthly delivery of the Escrituração Fiscal Digital das Contribuiçóes (EFD) to PIS/ Cofins until the 10th business day of the second month after competence
Change of competence maturity 3, 4, and 5 to October 20, November 20, and December 20, respectively. Applies only to the federal portion.

Financing of salaries for companies with annual sales between R\$ 360 thousand and R\$ 10 million. Payment in 30 months. No layoffs for two months.

Temporary exemption from IPI on domestically produced and imported goods that are necessary to combat COVID-19.

Temporary and partial reduction of ICMS on traded goods that are necessary to combat COVID-19.

Change of competences 3 and 4 for the following dates: competence $3=$ up to $08 / 20$; competence $4=$ up to $10 / 20$; absence of fine and interest.

Change in the maturity of competence 3 and 4 for the following dates: competence $3=$ up to $08 / 25$; competence $4=$ up to $10 / 25$; absence of fine and interest.

Change of the deadline for delivery of competence 2, 3, and 4 until 07/21/2020. Absence of penalty and interest.

Change of deadline for delivery of competence 2,3 , and 4 until $07 / 14 / 2020$. Absence of penalty and interest. Instruction of the Federal Revenue Service No $1,932 / 2020$ 
Table A1. (Continued)

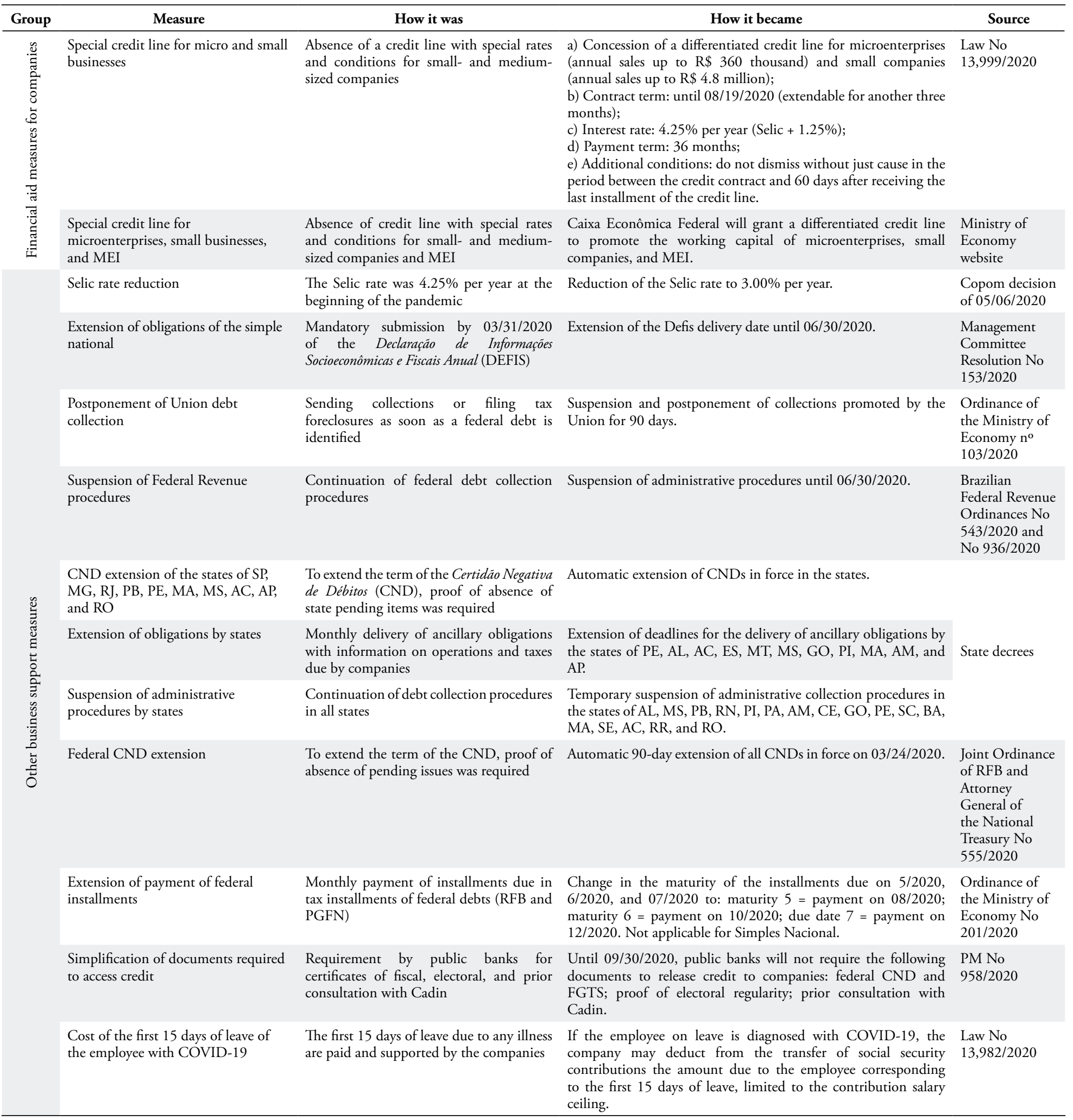




\section{ABSTRACT}

This teaching case presents the strategic positioning of the Magazine Luiza group (Magalu), represented by the director of institutional relations José Ribeiro and Luiza Helena Trajano, chairman of the Board of Directors, before and during COVID-19. The case's objective is to promote a reflection on the business strategies adopted in times of crisis. Since the beginning of the COVID-19 pandemic in Brazil, Luiza and Magalu have engaged in discussions and practiced a series of strategic actions for the benefit of the group's employees, small- and medium-sized companies, and those most affected by the pandemic. A few months after the first case, the instability was still perceived, it was still present, the number of infected and deaths rose and little was known about when the daily life would return to 'normal.' Many questions persisted about Magalu's next steps. Thus, it was necessary to discuss how the group should position itself to ensure performance and reputation. The proposal is to make students put themselves in the place of José Ribeiro, director of institutional relations and the urgent affairs commission of Magalu, in order to encourage a debate about the market and non-market strategies that could be implemented.

Keywords: times of crisis; nonmarket strategies; market strategies; Luiza Helena Trajano; Magalu Group.

\section{Learning objectives}

The present case was developed for application in the undergraduate course in Business Administration and in lato sensu and stricto sensu postgraduate courses in Management, in the disciplines of Business Strategies, in sessions that address concepts related to market and non-market strategies. It is expected that the student develops an understanding of how to position himself strategically in times of crisis and how to implement non-market strategies integrated with those of the market. It is also hoped that the student will be able to critically evaluate the strategies already adopted by Luiza and Magalu and design new scenarios. Therefore, the didactic objectives are: (a) to understand the adoption of business strategies in times of crisis; (b) develop the integration of market and nonmarket strategies; and (c) discuss possible market and nonmarket strategies that can be implemented, their opportunities and risks.

\section{Data sources}

This teaching case was based on truthful facts brought to the public through the media and social networks. Therefore, the methodology used for its construction considered, in its entirety, secondary data, obtained through printed and digital

\section{RESUMO}

Este caso para ensino apresenta o posicionamento estratégico do grupo Magazine Luiza (Magalu), representado pelo diretor de relaçóes institucionais José Ribeiro e Luiza Helena Trajano, presidente do Conselho de Administraçáo, antes e durante a COVID-19. O objetivo é promover uma reflexão sobre as estratégias empresariais adotadas em tempos de crise. Desde o início da COVID-19 no Brasil, Luiza e o Magalu engajaram-se nas discussôes e praticaram uma série de ações estratégicas em benefício dos funcionários do grupo, das pequenas e médias empresas e dos mais afetados pela pandemia. Passados alguns meses dos primeiros casos, a instabilidade ainda era percebida, o número de infectados e mortes subia e pouco se sabia sobre quando o cotidiano retornaria ao 'normal'. Muitos questionamentos persistiam sobre os próximos passos do Magalu. Assim, era necessário discutir sobre como o grupo deveria se posicionar para assegurar seu desempenho e sua reputação. A proposta é que os alunos se coloquem no lugar de José Ribeiro, diretor de relações institucionais, e do comitê de assuntos urgentes do Magalu, a fim de propiciar um debate acerca das estratégias de mercado e de não mercado que poderiam ser implementadas.

Palavras-chave: tempos de crise; estratégias de não mercado; estratégias de mercado; Luiza Helena Trajano; Grupo Magalu.

media (reports from national and international magazines, internet pages, websites of the organizations mentioned in the case, and the Brazilian Federal Government), as well as public social networks of the characters mentioned (Instagram — @luizahelenatrajano; LinkedIn — /luizahelenatrajano; and YouTube - named Luiza Helena Trajano). At no time was it used information and internal data of those mentioned. Thus, it is a problem situation led by real people, with writing based on public sources, such as: Exame, Época Negócios, UOL Economia, Valor Econômico, InfoMoney, NSC Total, BBC Brasil, G1-Globo, IstoÉ, Folha de S.Paulo, O Globo, Estadão Economia \& Negócios, Você S/A from Editora Abril, R7 Notícias, Rádio Itatiaia, InvestNews $B R$, Magazine Luiza website, , Brazilian Women Group website, BNDES website, and Senado Federal website. For didactic purposes, the authors created the figure of Magalu's director of institutional relations, Mr. José Ribeiro, who acted as the protagonist of the case. However, it should be emphasized that the case is intended for debate in an academic environment, with the sole purpose of teaching. Finally, it is pointed out that the interpretation given by the authors to the facts mentioned in the case was built from the collected collections. 


\section{Teaching plan}

When applying to the teaching plan, it is suggested that the case be made available to students in advance for reading and that the teacher open the discussion in plenary, explaining the dynamics of the case analysis. An initial discussion of the transition questions (TQs) in small groups is advised and then the plenary discussion, in the large group, of the discussion questions. Finally, the teacher must close the discussions with a mapping of the students' speeches relating to the theoretical concepts underlying the case. Table 1 shows the proposed time distribution for applying the case.

Table 1. Suggestion for the distribution of the timetable for applying the case for teaching.

\begin{tabular}{lc}
\hline \multicolumn{1}{c}{ Activities } & Duration (minutes) \\
\hline Opening of the case discussion in plenary & 5 \\
Discussion of issues in small groups & 25 \\
Discussion of issues in the large group & 55 \\
Closing of discussions & 15 \\
\hline
\end{tabular}

Note. Prepared by the authors.

\section{Opening of the case discussion in plenary}

At the opening, it is suggested that the teacher ask small groups (of three or four students) to discuss the market environment in which Magalu was inserted and specify resources and capabilities that the group owned and employed to face COVID-19. Then, discuss the non-market environment, identify the non-market strategies used, and reflect on how personal relationships guide these strategies. With such knowledge, students will be prepared to examine the integration of market and non-market strategies used by Magalu and to point out improvements and other strategies that could be implemented.

In the plenary discussion, in the large group, it is proposed that students debate the proposed questions, based on the perceptions, ideas, and directions raised in small groups. The teacher should mediate the debate, discussing the issues raised by the students and confronting them in order to better understand their arguments and positions. It is also proposed to induce students to rethink the opportunities and risks of the strategies proposed by them, and to highlight the need to consider the market and nonmarket environment and Magalu's resources and capabilities to explore the strategies and generate competitive advantage. Finally, the teacher must close the discussions with a mapping of what was discussed.

\section{Plenary case analysis supported by literature}

Considering the educational objectives, the following are proposed three axes with questions developed in order to stimulate the analysis of the case in plenary. The first axis includes discussions about market strategies; the second, discussions on non-market strategies; and the third on the integration of market strategies with nonmarket strategies. These questions can be modified at the teacher's discretion, to better adhere to his teaching plan.

\section{Axis 1. Market strategies in times of crisis}

Question 1. Analyze the external factors of the market environment in which Magalu was inserted.

The purpose of the first question is to examine the market environment. In times of crisis, one of the main aspects that must be considered is the analysis of the macro environment, in an accurate investigation of the political, economic, social, and technological factors (PEST) involved in the business (Johnson, Scholes, \& Whittington, 2005). In this case, Magalu, like other companies, was immersed in the COVID-19 crisis, which, although it was a public health crisis, was also an economic, social, and political crisis, with consequences in different areas of society; therefore, both political and business leaders needed to make emergency decisions considering the uncertainties of that scenario (Tourish, 2020).

The first half of 2020 was marked by a series of changes and impacts on the world and domestic scenario. With the pandemic, political tensions have gained strength between countries. There were countries in which their leaders took action to face the pandemic; in others, the leaders were not so favorable to solving the problem. COVID-19 impacted all economies. There was not a country that did not feel any economic shock after the quarantine. The economic and health debate was on, there were those who were vehemently in favor of health, many others argued that the economy needed to be the main point. Social inequality was increasingly latent, which led more people to ask for measures related to the control of the pandemic, but without forgetting the economic support. In addition, companies faced great challenges to maintain and innovate, using technology to their advantage (Barki \& Arcuri, 2020; Sandroni, 2020).

In Brazil, the first case of COVID-19 was registered in February 2020, and in mid-March the first death caused by SARS-CoV-2 was observed, and then the disease spread throughout the country. Then, social isolation was established, but the problem was that there was no forecast of returning to normal. The IMF predicted that, as a result 
of the isolation, Brazilian GDP would fall $5.3 \%$ and the unemployment rate would reach $14.7 \%$. The Federal Government, pressured by businessmen and fearing yet another huge crisis, implemented a series of PMs. Still, it was observed that after a few months of the first cases observed in the country, in July 2020, instability was still perceived, the number of cases and deaths rose, and little was known about when the daily life would return to 'normal.'

Question 2. Analyze the resources and capabilities of the market environment that the Magalu group had before COVID-19 emerged and which ones it employed during the pandemic.

The objective of the second question is to identify the market-related resources and capabilities that Magalu had before COVID-19 and which it employed during the pandemic. To guide the discussion, TQ proposals are suggested, namely:

TQ 1. What resources and capabilities of the market environment did Magalu have before COVID-19?

Resources can be understood as assets (tangible and intangible) of a company, at a given moment, which sustain its strengths and weaknesses (Wernerfelt, 1984). Capabilities consist of the company's skills to adapt, integrate, and reconfigure resources and competencies to meet market changes (Teece, Pisano, \& Shuen, 1997). Analyzing the case under study, Magalu has invested in the automation and computerization of its stores since 1980 and, in 1992, launched the first virtual stores. Its salespeople made online sales through an application implemented in 2016, however, in a restricted way. In 2017 , it incorporated Integra, focused on the integration of e-commerce and marketplaces, and in 2018 it acquired Softbox, a developer of online sales services for retail companies, and Logbee, a startup specialized in logistics technology. In other words, Magalu had resources and capabilities that enabled the launch of Parceiro Magalu, in the midst of the pandemic, a digital platform that aimed to ensure online sales and provide a new source of income for people who were fired.

TQ 2. What are the resources and capabilities of the market environment that the Magalu group employed during COVID-19?

During the pandemic, Magalu approved the issuance of 800 million reais in debentures, renegotiated contracts with suppliers, made cost cuts unrelated to people, suspended investments, and reduced the salaries of executives and directors for a period of three months. It also enabled channels for online sales in the home office; integrated the application already used to the most popular social networks; and launched the Parceiro Magalu, a digital platform for selling the group's products and other trades offered in the marketplace. It set up a team of engineers within the innovation laboratories, to monitor the cases of COVID-19 in the cities where physical stores were located.

\section{Axis 2. Non-market strategy in times of crisis}

Question 3. Analyze the non-market environment in which the Magalu group was inserted.

The non-market environment consists of the social, political, and legal arrangements that structure the organization's interactions with stakeholders governments and the public — in order to maximize the performance of organizations (Baron, 1995). The objective of the third question is to assess the four Is issue, interests, institutions, and information - by Baron, which characterized the non-market environment in which the Magalu group was inserted. Therefore, it is necessary to recognize the social and political issues relevant to the company that can generate a new opportunity (issue); the interests of the actors involved in the issues identified, to diagnose potential allies and key opponents (interests); the main institutions that work under the identified issues, to better plan the company's performance (institutions); and the information that the actors involved have on the issues identified and that can affect them in the arena (information). When analyzing the case, it is clear that Luiza and the group acted like this:

(1) Issue: acting on political fronts, in discussions of government programs and PMs, as well as donations to political electoral campaigns; and social fronts, with actions developed internally by Magalu, with involvement with different institutes, NGOs, and social projects developed by the public, private, and third sectors and philanthropic donations.

(2) Interests: the actions (issues) were carried out by both Luiza and the Magalu group. Luiza was in the political arena (for example, at the meeting with then President Dilma Rousseff through the Brazilian Women Group). Magalu has been a partner of the Federal Government for years (for example, in the Computador para Todos programs, via funding from BNDES, and Minha Casa Minha Vida and Minha Casa Melhor, by Caixa Econômica Federal), in addition to donations to electoral campaigns carried out by various political parties and candidates. With regard to social actions, Magalu was associated with different institutes, NGOs, and social projects developed by the public, private, and third sectors. It had internal initiatives 
and partnerships with suppliers to ensure the group's social and environmental responsibility. Financially, it supported the Cancer Hospital and Santa Casa de Franca (SP) and made philanthropic donations giving priority to schools, women's police stations, hospitals, nursing homes, and APAEs. During COVID-19, it contributed with monetary donations, equipment, and supplies for the treatment of pandemic victims.

(3) Institutions: relationships with government and social agencies. On the political front, Luiza maintained relationships with several political actors. For example, for the construction of PMs to confront COVID-19, Luiza found several secretaries (including the secretary of the treasury) and acted in the dissemination of the measures. On the social front, the businesswoman chaired the Brazilian Women Group and, in partnership with Sebrae, offered training for small- and medium-sized companies. Magalu, in turn, had numerous partnerships (to name, Instituto Ethos, Instituto Pró-Criança, NGO World Wildlife Fund, APAEs); adhered to the Pact of Commitment and Attitude under the Maria da Penha Law, promoted by the Secretariat of Policies for Women, of the Presidency of the Republic, and invested in social projects through the National Program to Support Oncological Care and the National Program to Support Health Care for People with Disabilities. It also contributed to the Municipal Fund for Children and Adolescents.

(4) Information: the literature reports that the information obtained through political and social interactions usually has the purpose of meeting the objectives of organizations, related to their shareholders and stakeholders, in order to obtain a sustained competitive advantage (Baron, 1995). In this sense, Luiza and Magalu have been active during the COVID-19 pandemic in publicizing the measures adopted by the Federal Government, as well as by local governments in municipalities where physical stores are installed.

Question 4. What non-market strategies were implemented by the Magalu group, represented by the director of institutional relations José Ribeiro and the urgent affairs committee, and by Luiza, before and during COVID-19? And how do personal relationships guide these strategies?

The objective of the fourth question is to debate the political and social strategies used by Luiza as a public person and by Magalu, before and during COVID-19, as well as to reflect on how Luiza's personal relationships guide these strategies. Therefore, TQs are suggested in order to guide the discussion:

TQ 1. What were the political strategies used by Magalu, represented by José Ribeiro, the urgent affairs committee, and Luiza, before and during COVID-19?
Corporate political activities (CPA), as named in the literature on non-market strategies, consist of "any deliberate action by the firm designed to influence government policy or process" (Getz, 1997, p. 32). They refer to the actions that companies take in order to get closer to the government and influence the formulation of government policies to achieve superior results (Hillman, Keim, \& Schuler, 2004). In the case under study, it was observed that, before COVID-19, Luiza and Magalu, represented by José Ribeiro, stood out for their proximity to the political environment. In 2006, Magalu was approved as a partner of the Federal Government's digital inclusion program Computador para Todos. While donations to electoral campaigns were allowed, José Ribeiro, together with his team, was active in the decisions so that the group was active in this regard. In 2011, Luiza was invited to occupy a ministry in the Dilma government, refusing it. In 2013, José Ribeiro, at the head of Magalu's institutional relations, participated directly in the discussions of Minha Casa Melhor with the Federal Government. At the request of President Dilma Rousseff, in 2014, Luiza held a presidential meeting with about one hundred businesswomen from Brazilian Women Group. During COVID-19, Luiza was with the government and other bodies for the creation of PMs and later helped to disseminate them, simplifying communication on her social media.

TQ 2. What were the social strategies used by Magalu, represented by José Ribeiro, the urgent affairs committee, and Luiza, before and during COVID-19?

Social or CSR strategies refer to actions that companies take considering their responsibilities to stakeholders. They are designed to alleviate or prevent social pressure and can be used in marketing and reputation building (Baron, 2016). In this case, it was observed that Luiza and Magalu, represented by José Ribeiro, acted in some social strategies before COVID-19. Luiza gave lectures to assist the management of small- and mediumsized companies and led the Brazilian Women Group. Magalu was associated with different institutes, NGOs, and social projects developed by the public, private, and third sectors. Financially, it supported the Cancer Hospital and Santa Casa de Franca (SP). Its employees were engaged in social actions and their suppliers needed to comply with legislation regarding the preservation of the environment, respect for people, and human rights. Magalu maintained policies and practices for environmental preservation and awareness and developed programs for inclusion and respect for differences within the organization, such as the inclusion of a specific clause on social and environmental responsibility in contracts with suppliers, carried out by José Ribeiro in 2010. It donated to philanthropic 
organizations prioritizing schools, women's police stations, hospitals, nursing homes, and APAEs.

During COVID-19, Luiza, in partnership with Sebrae, offered training for small- and medium-sized companies and, from the Brazilian Women Group, considering the increase in cases of violence against women, carried out campaigns to expand complaints against the aggressors. Magalu, through José Ribeiro and the urgent affairs committee, was one of the first organizations to adhere to social isolation and commit to preserving jobs. It allocated free shipping to the product categories of immediate need in order to collaborate with the entire corporate philanthropy movement that was happening in the country. It contributed with monetary donations, equipment, and supplies for the treatment of victims of the pandemic. It also launched Parceiro Magalu, which, in addition to being a market strategy, made it possible for dismissed people to have a source of income, and for MEI and small retailers to sell their products online.

TQ 3. How do personal relationships guide the nonmarket strategies used by Magalu?

Analyzing the case, it was found that political and social strategies were implemented by Luiza as a public figure, and by Magalu as a company. Luiza excelled as an influential business leader during COVID-19. She participated in interviews, engaged in media discussions, was with the Federal Government in the creation of PMs, and carried out social initiatives, such as training for smalland medium-sized companies and campaigns to expand reports of cases of violence against women. However, although Luiza remains at the forefront of these actions, since 2016 Frederico Trajano assumed the position of CEO of Magalu while she started to act as chairman of the board of directors, which raises the reflection on the extent to which the political and social actions of Luiza favor the group and the extent to which the group should continue to be guided by the businesswoman.

The non-market strategy literature suggests that nonmarket strategies used by companies to gain influence and controlover theenvironment beyond the market may include lobbying, campaign contributions, public relations, and building personal and organizational ties with institutions and sociopolitical actors (Sun, Mellahi, \& Wright, 2012). In other words, personal ties are part of the companies' non-market strategies, thus, it is suggested as a discussion the fact that Luiza remains ahead of the actions in place of the current $\mathrm{CEO}$, and the importance of the relationships built by Luiza as a mechanism of non-market strategy. These personal relationships in the non-market strategies implemented by Magalu can be explored by students to discuss improvements and implement new strategies to face the crisis.

\section{Axis 3. Integration of market and non- market strategies in times of crisis}

Question 5. Examine the integration of the market and non-market strategies used by Magalu. Point out improvements, as well as what other strategies could be implemented to face the crisis.

The purpose of this question is to reflect on the integration of strategies. A business strategy presents market and non-market scenarios and, to ensure the performance and reputation of the group, an integrated strategy that seeks synergy between market and nonmarket must be considered in order to face and defend environmental factors (Baron, 1995). Therefore, in order to guide the discussion, TQs are suggested:

TQ 1. Examine the integration of Magalu group's market and non-market strategies.

Companies are inserted and compete in the market and non-market environment (Baron, 1995; Doh, Lawton, \& Rajwani, 2012). Specifically, the market environment includes interactions between the company and other parties intermediated by markets or private agreements (for example, customers, competitors, and suppliers). On the other hand, the non-market environment includes interactions that are mediated by regulators, governments, citizens, NGOs, activists, and the media. Organizational performance depends on integrating market strategies with non-market strategies. Thus, the way to develop such integration can be the differential with regard to the superior result of a company (Baron, 1995).

Analyzing the case and after answering the previous questions, it was observed that Magalu acted, both before and during the COVID-19 crisis, in market strategies (questions in axis 1) and in non-market strategies (questions in axis 2), as shown in Table 2. An organization must weigh the interests of its main stakeholders, without neglecting the concern for shareholders' profitability. The integration of market and non-market strategies may have provided Luiza and Magalu with good performance in facing the crisis. In addition, the fact that both the businesswoman and the group have already developed such integrated strategic actions has given them a competitive advantage in facing the pandemic, in relation to competitors, and in directing government measures. 
Table 2. Main market and non-market strategies of the Magalu group.

\begin{tabular}{l}
\hline Market strategies \\
\hline Automation and computerization of stores \\
E-commerce and marketplaces (for example, the launch of Parceiro Magalu during COVID-19) \\
\hline Non-market strategies \\
\hline Donations to election campaigns \\
Participation in discussion of government programs and PMs during COVID-19 \\
Government program partner \\
Lectures to assist the management of small- and medium-sized companies \\
Association in institutes, NGOs, and social projects developed by the public, private, and third sectors \\
Financial support to the Cancer Hospital and Santa Casa de Franca (SP) \\
Environmental preservation and awareness policies and practices \\
Inclusion programs and respect for differences within the organization \\
Philanthropic donations giving priority to schools, women's police stations, hospitals, nursing homes, and APAEs \\
Monetary donations, equipment, and supplies for the treatment of pandemic victims \\
\hline
\end{tabular}

Note. Elaborated by the authors.

TQ 2. What improvements or new strategies could be implemented by the Magalu group to face COVID-19?

In this question, it is intended to provoke the student to deepen his knowledge in the tactics of nonmarket strategies, as well as to suggest to Magalu and the companies in general ways to develop the integration of the strategies. Non-market strategies have several forms of implementation (Getz, 1997). On the political front, it is possible to mention donations to campaigns that Magalu has already carried out via legal entities and which were later banned in Brazil. One way to continue acting in this strategy is to make donations through individuals (owners, for example). The presence of ex-politicians on the boards of directors is also a form of political action and can be a tactic to be explored by the group, in the same way as the lobby. On the social front, both Luiza and Magalu were active. Investing in philanthropy, in CSR, or in the active management of media actors can reflect value for organizations and maintain their reputation.

TQ 3. What trade-offs can Magalu face between market and non-market strategies?

In this question, we intend to bring up the discussion on trade-offs between market and non-market strategies. For example, Magalu's non-dismissal policy is valid and linked to the company's reputation, but how to deal with it if the pandemic takes too long? What are the risks and gains involved? The pandemic has been going on for nine months (from March to December) and has a tendency to go on longer. The Brazilian government extended PMs to combat COVID-19 until September 2020, and the unemployment rate in Brazil was $14.6 \%$ in the third quarter of 2020, having an upward trend. In addition, the projected drop in GDP by Ipea is 6\% (Ipea - July 2020 economic scenario). All of these points constitute a trend that the economic and fiscal problems for the coming years should continue. Should Magalu continue to participate in government program discussions? What are the risks and gains in maintaining non-market strategies to the detriment of those for Magalu? These are some questions that students can seek to answer for the discussion on trade-offs.

\section{Closure of the case discussion}

In closing the case, it is suggested that the teacher map the students' speeches, relating them to the main theoretical concepts underlying the case, and provoke reflections on the postures of Brazilian companies from other business contexts in times of crisis. It is also proposed that students design strategies that the Magalu group can use to face the impacts caused by COVID-19, which contemplate in an integrated manner market and nonmarket strategies. 


\section{REFERENCES}

Barki, E., \& Arcuri, A. (2020). Chegou a hora de uma nova visão de negócios. GV-Executivo, 19(2). Retrieved from https:// rae.fgv.br/gv-executivo/vol19-num2-2020/chegou-horanova-visao-negocios

Baron, D. P. (1995). Integrated Strategy: Market and Nonmarket Components. California Management Review, 37(2), 4765. https://doi.org/10.2307\%2F41165788

Baron, D. P. (2016). Strategy beyond markets: A step back and a look forward (Chap. 34, pp. 411-434). Bradford, UK: Emerald Group.

Doh, J. P., Lawton, T. C., \& Rajwani, T. (2012). Advancing nonmarket strategy research: Institutional perspectives in a changing world. Academy of Management Perspectives, 26(3), 22-39. https://doi.org/10.5465/amp.2012.0041

Getz, K. A. (1997). Research in corporate political action: Integration and assessment. Business \& Society, 36(1), 3272. https://doi.org/10.1177\%2F000765039703600103

Hillman, A. J., Keim, G. D., \& Schuler, D. (2004). Corporate political activity: A review and research agenda. Journal of Management, 30(6), 837-857. https://doi.org/10.1016\%2Fj.jm.2004.06.003
Johnson, G. Scholes, K., \& Whittington, R. (2005). Explorando a Estratégia Corporativa (7th ed.). Porto Alegre: Bookman.

Sandroni, P. (2020). Pandemia: A propósito de um falso dilema. GV-Executivo, 19(2). https://rae.fgv.br/gv-executivo/ vol19-num2-2020/pandemia-proposito-falso-dilema

Sun, P., Mellahi, K., \& Wright, M. (2012). The contingent value of corporate political ties. Academy of Management Perspectives, 26(3), 68-82. https://doi.org/10.5465/amp.2011.0164

Teece, D. J., Pisano, G., \& Shuen, A. (1997). Dynamic capabilities and strategic management. Strategic Management Journal, 18(7), 509-533. https://doi.org/10.1002/ (SICI) 1097-0266(199708) 18:7\%3C509::AIDSMJ882\%3E3.0.CO;2-Z

Tourish, D. (2020). Introduction to the special issue: Why the coronavirus crisisisalsoacrisisofleadership.Leadership, 16(3) 1-12. https://doi.org/10.1177\%2F1742715020929242

Wernerfelt, B. (1984). A resource-based view of the firm. Strategic Management Journal, 5(2), 171-180. Retrieved from https://www.jstor.org/stable/2486175 


\section{Authorship}

\section{Ana Paula Pereira dos Passos}

Universidade do Vale do Itajaí, Programa de Pós-graduação em Administração

Rua Uruguai, nº 458, Centro, 88302-202, Itajaí, SC, Brazil.

E-mail address: passosapp@gmail.com

(D) https://orcid.org/0000-0003-0684-8582

\section{Eleandra Maria Prigol Meneghini*}

Universidade do Vale do Itajaí, Programa de Pós-graduação em Administração

Rua Uruguai, nº 458, Centro, 88302-202, Itajaí, SC, Brazil.

E-mail address: eleandra.meneghini@gmail.com

(D) https://orcid.org/0000-0002-2961-882X

\section{Marina Amado Bahia Gama}

Fundação Getulio Vargas, Escola de Administração de Empresas de São Paulo

Av. Nove de Julho, no 2029, Bela Vista, 01313-902, São Paulo, SP, Brazil.

E-mail address: abgama@gmail.com

(D) https://orcid.org/0000-0003-2154-1984

\section{Jeferson Lana}

Universidade do Vale do Itajaí, Programa de Pós-graduação em Administração

Rua Uruguai, n 458, Centro, 88302-202, Itajaí, SC, Brazil.

E-mail address: jlana@univali.br

(D) https://orcid.org/0000-0002-9787-1114

* Corresponding Author

\section{Funding}

The authors thank the Coordenação de Aperfeiçoamento de Pessoal de Nível Superior (CAPES) for the financial support granted for the research of this article.

\section{Conflict of Interests}

The authors have stated that there is no conflict of interest.

\section{Copyrights}

RAC owns the copyright to this content.

\section{Authors' Contributions}

$\mathbf{1}^{\text {st }}$ author: conceptualization (equal); investigation (equal); data curation (equal); writing-original draft (equal); validation (equal).

$2^{\text {nd }}$ author: conceptualization (equal); investigation (equal); data curation (equal); writing-original draft (equal); validation (equal).

$3^{\text {rd }}$ author: conceptualization (equal); investigation (equal); writing-original draft (equal); validation (equal).

$4^{\text {th }}$ author: conceptualization (equal); investigation (equal); writing-original draft (equal); validation (equal).

\section{Plagiarism Check}

The RAC maintains the practice of submitting all documents approved for publication to the plagiarism check, using specific tools, e.g.: iThenticate.

\section{Peer Review Method}

This content was evaluated using the double-blind peer review process. The disclosure of the reviewers' information on the first page, as well as the Peer Review Report, is made only after concluding the evaluation process, and with the voluntary consent of the respective reviewers and authors.

\section{Data Availability}

All data and materials have been made publicly available through the Harvard Dataverse platform and can be accessed at:

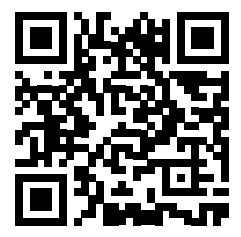

Ana Paula Pereira dos Passos; Eleandra Maria Prigol Meneghini; Marina Amado Bahia Gama; Jeferson Lana, 2021, "Replication Data for: Magalu has it": Social, political and market strategies during COVID-19", Harvard Dataverse, V1. https://doi.org/10.7910/DVN/OVEEDC

RAC encourages data sharing but, in compliance with ethical principles, it does not demand the disclosure of any means of identifying research subjects, preserving the privacy of research subjects. The practice of open data is to enable the reproducibility of results, and to ensure the unrestricted transparency of the results of the published research, without requiring the identity of research subjects. 